\title{
Pengembangan budaya masak abereng dalam peningkatan status gizi balita stunting di Desa Glagahwero, Kecamatan Panti, Kabupaten Jember dengan pendekatan agronursing
}

\author{
Hanny Rasni, ${ }^{1}$ Tantut Susanto, ${ }^{1,}$ Kholid Rosyidi Muhammad Nur, ${ }^{1}$ Novi Anoegrajekti ${ }^{2}$ \\ ${ }^{1}$ Departemen Keperawatan Komunitas, Keluarga, dan Gerontik, Fakultas Keperawatan, \\ Universitas Jember, Jember, Indonesia \\ ${ }^{2}$ Program Studi Sastra Indonesia, Fakultas IImu Budaya, Universitas Jember, Jember, Indonesia
}

\section{Submitted: 19 Januari 2019 Revised: 6 Februari 2019 Accepted: 21 Februari 2019}

\begin{abstract}
ABSTRAK Masyarakat Indonesia sebagian besar merupakan masyarakat agraris dengan hubungan kekeluargaan yang erat. Masyarakat agraris umumnya saling membantu dan menolong secara bersamasama, yang dikenal dalam bahasa Madura sebagai abereng. Tujuan pengabdian masyarakat dan penelitian ini adalah menjadikan kegiatan masak abereng sebagai potensi masyarakat desa dalam peningkatan status gizi balita stunting di Desa Glagahwero dengan pendekatan agronursing. Kegiatan berlangsung pada 4 Oktober - 14 Desember 2018 dan diikuti oleh 60 peserta (40 ibu beserta anak balitanya yang kurang gizi, 15 kader kesehatan penggerak posyandu, dan 5 perangkat desa). Pendekatan agronursing digunakan dalam mengidentifikasi sumber bahan makanan lokal desa yang dapat diolah bersama sebagai makanan yang bernilai gizi tinggi untuk balita. Rangkaian kegiatan terdiri dari sosialisasi, pelatihan, pembentukan kelompok penggiat masak, serah terima alat masak dan wadah makan, serta kegiatan masak bersama yang dilanjutkan makan bersama anak-anak balita dengan status nutrisi yang telah diukur. Rangkaian kegiatan tersebut dilakukan seminggu sekali selama sebulan. Dari 40 balita yang mengikuti kegiatan, hanya 20 balita yang rutin dan aktif mengikuti kegiatan selama 4 minggu masak abereng. Sebelum mengikuti program masak abereng, balita yang menjadi peserta dalam kegiatan ini mengalami kekurangan berat badan $1.000-$ $6.000 \mathrm{~g}$ berdasarkan usia dan jenis kelamin (sesuai standar NCHS WHO). Menu-menu yang dimasak sesuai dengan potensi masyarakat dan memiliki kandungan protein, vitamin, dan mineral yang tinggi. Setelah kegiatan masak abereng dilakukan sebanyak 4 kali selama satu bulan, terdapat kenaikan berat badan 200$1.000 \mathrm{~g}$. Masyarakat dan keluarga mampu menggali potensi, mengolah, dan menyajikan makanan lokal dari hasil pertanian sebagai makanan bernilai gizi untuk balita. Masak abereng dapat dijadikan sebagai sarana untuk meningkatkan status gizi balita stunting dengan pendekatan agronursing. Perilaku kemandirian masyarakat dalam peningkatan status gizi balita memerlukan tindak lanjut dari tenaga kesehatan dan akademisi secara berkelanjutan sehingga dapat menyelesaikan masalah kekurangan gizi pada anak.
\end{abstract}

KATA KUNCI masak abereng; balita; stunting; makanan lokal; agronursing

ABSTRACT Indonesian society is an agrarian society with close family relationship. Agrarian society generally helps each other together, which is known as "abereng" in Madura. The purpose of this community empowerment study is to make the "abereng" cooking activities as the villager's potency for improving the nutritional status of stunting children in Glagahwero Village with agronursing approach. The activities took place from 4 October to 14 December 2018 which was attended by 60 participants (40 mothers and their under-five children, 15 health cadres who mobilize "posyandu", and 5 village officials). An agronursing approach was used to identify local food resources that could be processed into foods with

\footnotetext{
*Corresponding author: Tantut Susanto

Departemen Keperawatan Komunitas, Keluarga, dan Gerontik, Fakultas Keperawatan, Universitas Jember, Jl. Kalimantan 37 Jember, Jawa Timur 68121, Indonesia

E-mail: tantut_s.psik@unej.ac.id
} 
high nutritional value. The activities consisted of socialization, training, establishment of cooking activists groups, handover of cooking utensils and food containers, cooking activities along with eating with underfive children with previously assessed nutritional status. The activities held in every week each month. Among 40 under-five children, only 20 of under-five children were actively participated in "abereng" cooking four times each month. Before intervention program, under-five children who participated in this activity experienced nutritional deficiencies ranged from 1000 to 6000 grams, based on age and sex (according to WHO NCHS standards). The menus were developed from local food resources which containing high level of protein, vitamins, and minerals. After "abereng" cooking was carried out four times each month, there was increasing of weight by 200-1000 grams. People and families were able to explore potentcy, process, and serve local foods as nutritious foods for toddlers. "Abereng" cooking activity is a potential community and family activity in the village for improving the nutritional status of stunting children with agronursing approach. Community independence in improving nutritional status of children requires continous followup from health workers and academics for resolving the problem of malnutrition in children.

KEYWORDS abereng cooking; under-five children; stunting; local food; agronursing

\section{Pendahuluan}

Gerakan Masyarakat Hidup Sehat (GERMAS) merupakan salah satu program yang sedang dijalankan pemerintah secara nasional. Salah satu sasarannya adalah ketercukupan gizi yang dikonsumsi oleh masyarakat termasuk anakanak yang sedang dalam masa pertumbuhan dan perkembangan. ${ }^{1}$ Anak usia di bawah lima tahun (balita) merupakan anak yang membutuhkan kecukupan gizi sebagai bekal untuk tumbuh dan berkembang optimal menuju masa depan yang sehat. Permasalahan gizi pada anak menjadi program prioritas dalam Program Indonesia Sehat dengan Pendekatan Keluarga (PISPK). ${ }^{2}$ Kekurangan gizi pada masa balita dapat menyebabkan permasalahan kesehatan yang kompleks, termasuk menyebabkan penurunan kekebalan sehingga meningkatkan risiko mengalami penyakit infeksi. ${ }^{3,4}$

Di Desa Glagahwero, Kecamatan Panti, Kabupaten Jember masih terdapat balita dengan kekurangan gizi, termasuk stunting, sebanyak lebih dari $40 \%$, berdasarkan pendataan awal oleh mahasiswa program pendidikan profesi ners. ${ }^{5}$ Kementerian Kesehatan Republik Indonesia pada tahun 2018 menyatakan bahwa prevalensi stunting pada anak berusia 2-5 tahun di Indonesia lebih dari 40\%. Pada tahun 2019 ditargetkan penurunan prevalensi stunting menjadi sebesar $30 \% .^{2}$ Upaya yang dapat dilakukan dalam mengatasi stunting adalah dengan pemberian makanan yang cukup secara jumlah dan kualitas serta pelaksanaan perilaku hidup bersih dan sehat pada anak berusia 2-5 tahun, pemberian air susu ibu (ASI) ekslusif pada anak usia 0-6 bulan, serta pemberian ASI dan makanan pendamping ASI (MPASI) yang berkualitas, cukup jumlah, dan sehat untuk anak berusia 6 bulan -2 tahun. ${ }^{1,2}$

Berdasarkan hasil analisis permasalahan di mitra pengabdian masyarakat didapatkan bahwa Perangkat Desa Glagahwero dan petugas kesehatan di salah satu pusat kesehatan masyarakat (puskesmas), yaitu Puskesmas Panti, menyatakan belum mendapatkan program yang tepat dalam menyelesaikan masalah kekurangan gizi pada balita. ${ }^{5}$ Kegiatan yang selama ini dilakukan adalah dengan pemberian penyuluhan kepada keluarga dan masyarakat tentang permasalahan stunting dan program Pemberian Makanan Tambahan (PMT), tetapi permasalahan kekurangan gizi masih terjadi. Perangkat desa kemudian mengajukan permohonan bantuan kepada akademisi di Universitas Jember dan dijawab dalam bentuk program Kuliah Kerja Nyata (KKN) sebagai alternatif penyelesaian masalah kekurangan gizi balita di Desa Glagahwero. ${ }^{5}$

Perangkat Desa Glagahwero dan kader kesehatan di desa tersebut menyatakan bahwa 
permasalahan stunting atau kekurangan gizi kronis disebabkan karena kurangnya pengetahuan dan keterampilan masyarakat, khususnya keluarga dengan balita, mengenai penyediaan gizi yang sesuai dengan kebutuhan balita walaupun penyuluhan kesehatan mengenai hal tersebut telah dilakukan. ${ }^{5}$ Perangkat desa juga menyampaikan bahwa hal tersebut kontradiktif dengan potensi alam yang ada di Desa Glagahwero. Desa Glagahwero sangat subur dengan berbagai macam tanaman yang dapat tumbuh dan hewan ternak yang melimpah untuk bahan pangan. ${ }^{5}$

Masyarakat Indonesia sebagian besar merupakan masyarakat agraris dengan hubungan kekeluargaan yang erat. Masyarakat agraris umumnya saling membantu dan menolong secara bersama-sama, yang dikenal dalam bahasa Madura sebagai abereng. Begitu juga masyarakat di Desa Glagahwero. Karena sudah menjadi kearifan lokal, budaya abereng mudah diterapkan dalam kegiatan memasak makanan bergizi. Dengan memasak abereng, pengetahuan dan keterampilan yang ingin disampaikan kemungkinan akan lebih mudah diterima masyarakat.

Tujuan pengabdian masyarakat dan penelitian ini adalah menjadikan kegiatan masak abereng sebagai potensi masyarakat dan keluarga di desa dalam upaya peningkatan status gizi balita stunting di Desa Glagahwero dengan pendekatan agronursing. Dengan pengabdian masyarakat dan penelitian ini, diharapkan terjadi peningkatan pengetahuan dan keterampilan memasak makanan bergizi pada keluarga yang memiliki balita. Selain itu, inisiasi kegiatan masak abereng yang dilanjutkan dengan makan bersama sebagai upaya peningkatan status gizi pada anak, kami harapkan dapat diteruskan di masa mendatang.

\section{Metode}

\subsection{Desain pengabdian masyarakat dan penelitian}

Kegiatan pengabdian masyarakat dan penelitian ini dilakukan dengan pendekatan kuantitatif dan kualitatif. Pendekatan kuantitatif digunakan dalam pengukuran berat badan, tinggi badan, dan pengumpulan data demografi seperti jenis kelamin dan usia anak balita. Pendekatan kualitatifdigunakan dalam mengeksplorasi persepsi masyarakat dan keluarga selama dan sesudah kegiatan masak abereng dilakukan. Analisis kualitatif digunakan melalui pendekatan diskusi terarah di antara kelompok perangkat desa dan ibu-ibu yang terlibat dalam kegiatan masak abereng. Topik dalam diskusi terarah berkaitan dengan masalah gizi anak, jenis bahan makanan, cara pengolahan jenis makanan, cara pemberian makanan kepada anak, dan tindak lanjut program. Kegiatan pengabdian masyarakat dan penelitian ini telah mendapatkan izin etik dengan nomor 187/UN25.8/KEPK/UT/2018.

\subsection{Prosedur dan pengukuran}

Kegiatan dilaksanakan dengan menggunakan pendekatan potensi wilayah. Intervensi berupa masak abereng dipilih sebagai solusi dalam meningkatkan status gizi balita. Pola pemberian makanan balita bersumber pangan lokal merupakan solusi terbaik dalam meningkatkan gizi anak. ${ }^{6}$ Pendekatan agronursing dipilih dalam upaya meningkatkan penggunaan hasil pertanian lokal sebagai sumber makanan bernilai gizi tinggi untuk anak balita. ${ }^{7}$

Kegiatan dimulai dengan mendapatkan data balita yang mengalami kekurangan gizi dan ibu dari balita tersebut, serta kader kesehatan yang akan diikutsertakan dalam kegiatan. Data diperoleh dari Kepala Desa Glagahwero. Kegiatan dilaksanakan selama kurang lebih 4 bulan, dari pengurusan izin sampai penulisan laporan, yaitu pada 4 Oktober - 14 Desember 2018. Kegiatan dimulai dengan sosialisasi, dilanjutkan dengan pelatihan, serta pembentukan kelompok penggiat masak abereng di Dusun Krajan dan Dusun Karangasem. Kegiatan masak abereng dilakukan sebanyak 4 kali, yaitu 1 kali seminggu di Kantor Desa Glagahwero selama 1 bulan. Pada setiap minggu dilakukan pengukuran berat badan dan tinggi badan balita. Kegiatan masak bersama dilanjutkan makan bersama pada kelompok balita kurang gizi. Kegiatan masak bersama dihadiri oleh Kepala Desa Glagahwero, Kepala Dusun Krajan dan Karangasem, ibu-ibu kader kesehatan, dan ibu-ibu beserta balitanya 
yang telah didata pada awal kegiatan dan diajak mengikuti rangkaian kegiatan.

Instrumen yang digunakan dalam pendataan data dasar balita adalah lembar Kartu Menuju Sehat (KMS) balita. Data yang diambil adalah usia dan jenis kelamin balita. Pengukuran berat badan dan tinggi badan dilakukan dengan menggunakan timbangan berat badan dan tinggi badan yang telah dikalibrasi sebelumnya.

Pengumpulan data kualitatif dilakukan dengan menggunakan metode diskusi terarah dengan panduan pertanyaan, pada masyarakat yang mengikuti kegiatan masak abereng. Pertanyaan yang diajukan berupa pertanyaan terbuka yang meliputi: (1) mengapa masalah gizi terjadi pada balita; (2) bahan makanan apa saja yang dapat dijadikan sumber MPASI; (3) bagaimana cara memasak dan menyiapkan makanan untuk balita; dan (4) bagaimana program lanjutan masak abereng yang diinginkan. Fasilitator diskusi memperoleh daftar pertanyaan tersebut secara tertulis dan menuliskan jawaban peserta diskusi dalam lembar jawab untuk menilai persepsi mereka terhadap kegiatan masak abereng. Berbagai macam kegiatan yang dilaksanakan disajikan dalam Gambar 1.

\subsection{Analisis hasil}

Data kuantitatif disajikan dalam frekuensi untuk data kontinu, sedangkan rerata dan standar deviasi digunakan dalam penyajian data numerik. Untuk mengetahui perbedaan status gizi balita sebelum dan sesudah kegiatan masak abereng dilakukan uji statistik paired t-test. Apabila nilai $p<0,05$, maka terdapat perbedaan bermakna.

Karakteristik peserta kegiatan disajikan secara kuantitatif. Bentuk partisipasi masyarakat dianalisis secara kualitatif dari hasil diskusi kelompok terarah mengenai metode masak abereng dengan pendekatan agronursing. Analisis kualitatif dilakukan dengan metode analisis tematik dari setiap pernyataan selama diskusi kelompok terarah. Hasil analisis tersebut juga digunakan sebagai masukan untuk perbaikan kegiatan masak abereng selanjutnya.

\section{Hasil}

\subsection{Profil anak balita}

Dari 40 anak balita yang mengikuti kegiatan di awal kegiatan, hanya 20 anak balita yang mengikuti kegiatan dari awal hingga akhir kegiatan dan datang setiap minggu selama sebulan. Tabel 1 menunjukkan data dari 20 anak balita tersebut.

Dari 20 anak balita yang mengikuti kegiatan secara penuh, terdapat rentang usia yang lebar, begitu pula kekurangan berat badan menurut jenis kelamin. Berdasarkan usia, terdapat rentang kekurangan berat badan yang besar, ada yang mengalami kekurangan berat badan $1.000 \mathrm{~g}$ dan ada yang sampai kekurangan berat badan $6.000 \mathrm{~g}$.

Selama kegiatan masak abereng, berat dan tinggi badan anak dimonitor tiap 2 minggu untuk mengevaluasi kemajuan penambahan berat badan anak. Tabel 2 menyajikan rerata kenaikan berat badan dan tinggi badan anak selama kegiatan berlangsung.

Dari 20 anak yang diukur berat badan dan tinggi badannya di akhir minggu kedua dan di akhir minggu keempat, diketahui bahwa terdapat peningkatan bermakna berat dan tinggi badan, lebih dari $1.000 \mathrm{~g}$ dan lebih dari $1 \mathrm{~cm}(p<0,001)$. Secara umum setiap anak mengalami kenaikan berat badan dan tinggi badan. Kegiatan masak abereng berhasil menaikkan berat badan dan tinggi badan, tetapi belum sampai menyelesaikan permasalahan kekurangan gizi pada anak.

\subsection{Persepsi ibu dan kader kesehatan mengenai status gizi anak}

Identifikasi dengan pertanyaan terbuka dalam diskusi kelompok terarah dari pertanyaan mengapa anak balita mengalami stunting dan kurang gizi menunjukkan gambaran tentang penyebab permasalahan stunting. Gambaran persepsi ibu dan kader kesehatan mengenai stunting yaitu berat badan dan tinggi badan yang tidak sesuai dengan usia, gagal tumbuh, kekurangan gizi, gangguan perkembangan, kerdil, pendek, pertumbuhan sangat lambat, susah makan, dan pertumbuhan 
Tabel 1. Distribusi usia, jenis kelamin, dan berat badan balita $(n=20)$

\begin{tabular}{ll}
\hline Karakteristik & \\
\hline $\begin{array}{l}\text { Usia (bulan, rerata } \pm \text { SD) } \\
\text { Jenis kelamin }\end{array}$ & $32 \pm 11$ \\
$\quad$ Laki-laki & $11(55,0)$ \\
$\quad$ Perempuan & $9(45,0)$ \\
Berat badan $(\mathrm{g}$, rerata \pm SD) & $13.275 \pm 1.650$ \\
\hline
\end{tabular}

Tabel 2. Pertambahan berat badan dan tingggi badan balita pada minggu kedua dan kempat kegiatan masak abereng $(n=20)$

\begin{tabular}{lcc}
\hline Variabel & Rerata \pm SD & $\boldsymbol{p}$ \\
\hline Berat badan $(\mathrm{g})$ & & \\
$\quad$ Minggu ke-2 & $10.872 \pm 1.723$ & $<0,001$ \\
$\quad$ Minggu ke-4 & $11.615 \pm 2.220$ & \\
Tinggi badan (cm) & & \\
$\quad$ Minggu ke-2 & $85,20 \pm 1,696$ & $<0,001$ \\
Minggu ke-4 & $86,25 \pm 1,742$ & \\
\hline
\end{tabular}

lambat. Sedangkan gambaran persepsi ibu dan kader kesehatan mengenai cara agar anak menjadi sehat adalah makan yang cukup, makan makanan sehat, makan makanan bergizi, makanan mengandung daging dan sayur-mayur, gizi seimbang, gizi dan istirahat yang teratur, dan memberikan gizi yang sesuai.

Gambaran cara ibu memberikan asupan gizi pada terbagi dalam 5 kategori, yaitu pemberian ASI dan MP-ASI, makanan 4 sehat dan 5 sempurna, lauk-pauk dan sayur-mayur, susu, dan buah-buahan. Gambaran makanan terakhir yang diberikan kepada anak terbagi dalam 14 kategori yaitu buah, susu, sayur bening dan sayur sop, wortel, ikan, telur, tempe, sosis kemasan, mie kemasan, semur kentang, bubur ayam, kacang ijo, ati ayam, dan teh manis kemasan.

Makanan yang disukai anak terbagi dalam 12 kategori, yaitu bubur tim ati ayam, kacang hijau, ikan, sayur bayam, tempe, pepes tongkol, dadar jagung, telur, sayur brokoli, perkedel kentang, daging ayam, dan tahu kecap. Keterampilan ibu dalam membuat menu terbagi dalam 6 kategori yaitu membuat bubur, mengolah sayur, membuat nasi goreng, mengolah telor, membuat kue, serta mengolah tempe dan tahu. Bahan pangan yang terdapat di lingkungan terbagi dalam 11 kategori yaitu bayam, daun kelor, kangkung, kacang panjang, wortel, pepaya, jagung, singkong, ubi, ayam, dan ikan lele. Harapan ibu dan kader kesehatan terhadap kegiatan masak abereng adalah dapat meningkatkan pengetahuan, mengurangi kasus kekurangan gizi, dan meningkatkan kesehatan.

\subsection{Penyusunan menu makanan untuk anak saat di rumah selama kegiatan masak abereng}

Ada 2 tema penyusunan menu makanan untuk anak yang dituliskan ibu, yaitu pemberian menu makanan lengkap dan pemberian menu makanan kudapan. Tema makanan lengkap dibagi dalam 2 kategori yaitu kategori menu nasi, sayur, lauk hewani, dan buah, serta kategori menu nasi, sayur, lauk hewani dan nabati, buah, dan susu. Sedangkan tema makanan kudapan dikategorikan dalam pemberian susu, buah, roti, bakpao, pisang keju, dan puding. Strategi ibu dalam upaya meningkatkan status gizi ada 2 , yaitu dengan memberikan makan 3 kali dalam sehari dan membiasakan memberikan makanan tinggi protein, vitamin, dan mineral. Keterbatasan ibu dalam pemberian asupan gizi pada anak dikategorikan menjadi 4, yaitu ibu menyatakan anak susah makan, anak mau makan jika diberi suplemen makanan, anak mau makan jika disuapi, dan peningkatan berat badan anak tidak stabil.

\section{Pembahasan}

Program pengabdian masyarakat dan penelitian berupa masak abereng ini berjalan sesuai dengan perencanaan. Masyarakat mampu memobilisasi potensi pangan lokal berdasarkan hasil pertaniannya (agronursing). ${ }^{7}$ Ibu balita belajar dengan mengidentifikasi nilai kandungan sumber makanan lokal yang kemudian dimasak bersama sesuai dengan jenis dan kandungan makanan. Selain itu, masyarakat belajar cara pengolahan makanan dan penyusunan makanan balita.

Kegiatan masak abereng ini merupakan 


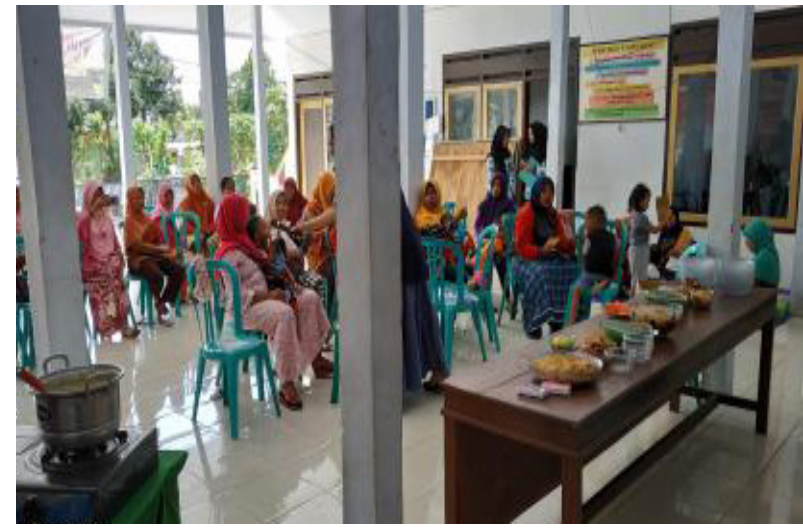

(a)

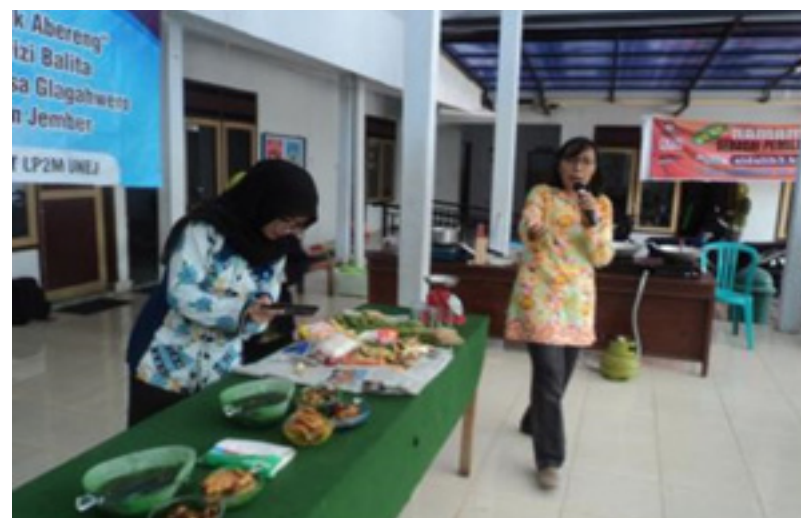

(c)

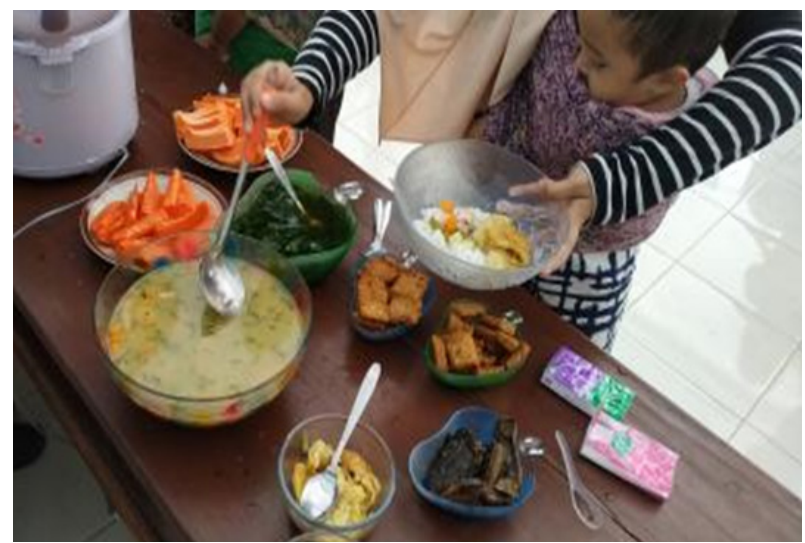

(e)

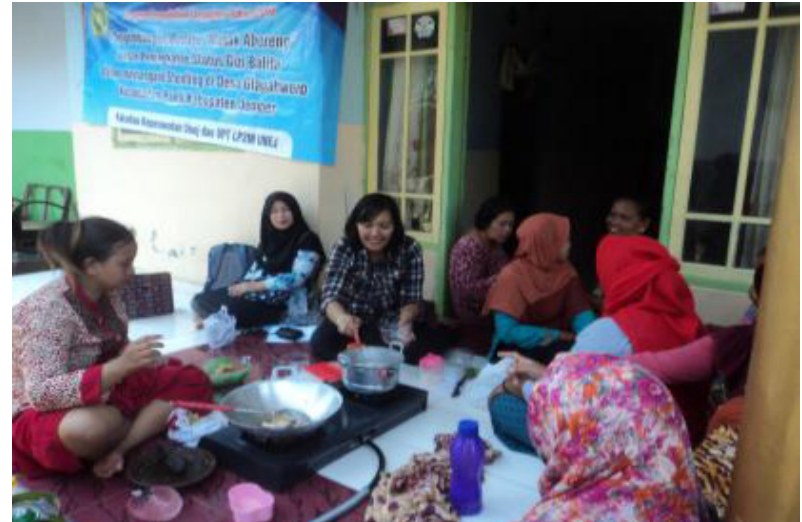

(b)

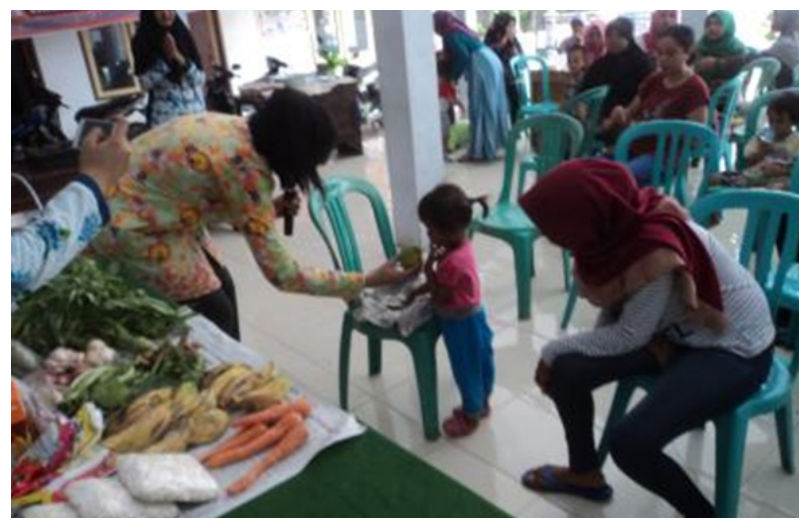

(d)

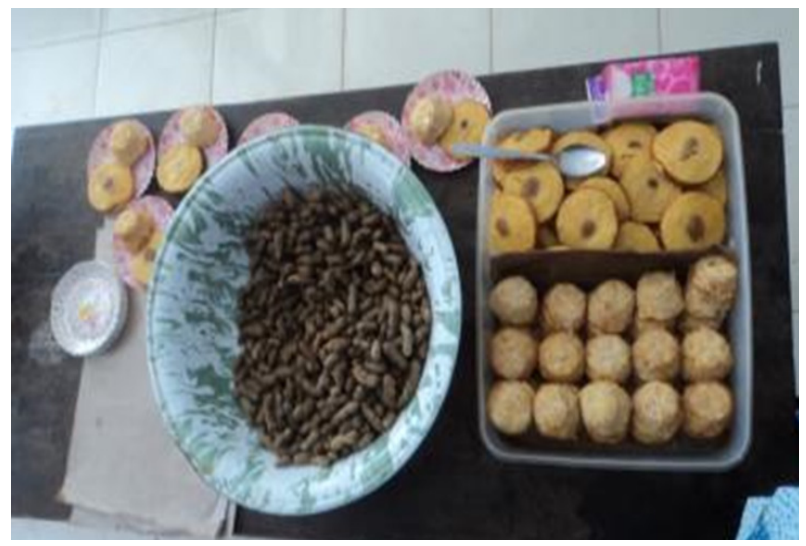

(f)

Gambar 1. Berbagai kegiatan yang dilaksanakan. (a) Masak abereng di Balai Desa Glagahwero. (b) Masak abereng di Posyandu Dusun Krajan. (c) Tanya jawab mengenai pengetahuan kebutuhan nutrisi pada anak balita. (d) Kegiatan anak memilih makanan sehat. (e) Makan bersama kelompok balita setelah masak abereng. (f) Berbagai jenis kudapan yang disajikan untuk anak balita

solusi alternatif dalam mengatasi permasalahan stunting. Kegiatan difokuskan pada pemberdayaan masyarakat untuk menyiapkan MPASI dalam meningkatkan status gizi anak. Penyusunan MPASI tersebut didasarkan pada makanan bersumber pangan lokal karena ternyata bahan pangan lokal kaya akan zat gizi untuk pertumbuhan anak dan dapat dioptimalkan dalam MPASI. ${ }^{8}$ Makanan bersumber pangan lokal dalam masak abereng dapat dijadikan alternatif dalam menyelesaikan masalah keterbatasan akses sumber pangan yang baik untuk anak balita. ${ }^{9}$ Pedoman dalam pemberian 
MPASI dalam masak abereng disesuaikan dengan pedoman pangan lokal dari panduan Dapur Ibuku Kementerian Kesehatan. ${ }^{10}$ Masak abereng dengan optimalisasi bahan pangan lokal dapat menjadi solusi untuk mengatasi masalah stunting pada balita melalui kegiatan pemberdayaan masyarakat.

Program pemberdayaan masyarakat merupakan suatu strategi yang dapat digunakan dalam meningkatkan potensi masyarakat dalam bidang kesehatan. Kegiatan masak abereng sebagai bagian dari kegiatan pemberdayaan masyarakat mampu meningkatkan partisipasi masyarakat. Kegiatan pemberdayaan masyarakat dan kemitraan bersama merupakan bagian dari kegiatan dalam meningkatkan keikutsertaan masyarakat dalam intervensi keperawatan komunitas. ${ }^{11}$ Kegiatan optimalisasi keluarga dengan pendekatan lintas budaya dapat meningkatkan cakupan layanan kegiatan peningkatan gizi anak. ${ }^{12}$ Selain itu, program gerakan bebas gizi buruk di masyarakat dapat dilakukan melalui optimalisasi pos pelayanan terpadu (posyandu) plus dengan kerja sama lintas program dan sektoral. ${ }^{13}$ Oleh karena itu, keikutsertaan masyarakat dan keluarga dapat dioptimalkan dengan kegiatan pemberdayaan dan kemitraan dalam bidang kesehatan dalam mengatasi masalah kurang gizi pada balita.

Berdasarkan hasil intervensi selama minggu kedua dan akhir minggu keempat, kegiatan masak abereng mampu menaikan berat badan dan tinggi badan anak. Balita (usia 1-5 tahun) membutuhkan energi 1.000-1.900 kalori per hari, kalsium sekitar $500 \mathrm{mg}$ per hari, dan zat besi $7 \mathrm{mg}$ per hari. Program optimalisasi pangan bersumber pertanian lokal merupakan strategi yang tepat dalam mengatasi masalah gizi pada balita. Penelitian terdahulu menyatakan bahwa pemberian sumber pangan lokal dapat menaikkan berat badan anak di masyarakat. ${ }^{6}$ Berdasarkan analisis kualitatif, program masak abereng menyebabkan masyarakat belajar menyiapkan makanan anak. Hal tersebut sangat menentukan bagaimana cara pemilihan sumber gizi untuk anak yang tepat ${ }^{14}$ karena akan menentukan pertumbuhan dan perkembangan anak dengan ditunjang zat gizi yang bergizi. ${ }^{15}$ Optimalisasi intervensi berbasis keluarga dan terapi keluarga dapat meningkatkan kemandirian keluarga terhadap permasalahan kesehatannya, ${ }^{16}$ seperti dengan melakukan home care atau kunjungan rumah $^{17}$ terutama pada kelompok rentan dan berisiko di masyarakat. ${ }^{18}$ Oleh karena itu, pendekatan keluarga sebagai unit terkecil di masyarakat perlu terus ditingkatkan dalam upaya peningkatan status kesehatan setiap anggota keluarga di masyarakat.

Dalam kegiatan pengabdian dan penelitian ini, para ibu dapat menyusun menu dan menentukan pola makan terbaik untuk balita. Karakteristik pola makan balita terkait dengan pemenuhan kebutuhan gizi perlu diperhatikan karena dapat memengaruhi status gizinya. Keluarga sebagai sistem dapat meningkatkan fungsinya dalam perawatan kesehatan anggota keluarga dalam mencapai siklus perkembangan keluarga yang optimal. ${ }^{19}$ Keluarga mandiri dalam pemenuhan gizi pada balita dapat diartikan bahwa keluarga mampu mengukur status gizi balita, keluarga mampu mengakses sumber-sumber terkait pencapaian status gizi baik pada balita, keluarga mampu menyediakan dan memberikan pemenuhan gizi sesuai kebutuhan pada balita, keluarga mampu menunjukkan keterampilan upaya peningkatan status gizi baik pada anak dan status kesehatan anak, serta keluarga mampu memelihara kebersihan diri dan lingkungan serta mencegah terjadinya masalah gizi dan masalah kesehatan.

Kesukaan makanan anak yang disampaikan oleh ibu menunjukkan bahwa anak menyukai makanan olahan rumah. Hal ini menunjukkan adanya kemauan makan dari anak. Dengan adanya kemauan makan dari anak maka keluarga perlu memfasilitasi makan anak. Keadaaan kekurangan gizi pada anak dimungkinkan karena kurang optimalnya keluarga dalam pemanfaatan sumber daya alam yang ada di lingkungan rumah. Hal ini diketahui dari banyaknya bahan pangan yang mudah didapatkan di lingkungan tersebut tetapi keluarga kurang dapat mengolah dan menyajikan 
makanan untuk anak.

Data keadaan status gizi anak, gambaran pemenuhan gizi anak, dan potensi alam di Desa Glagahwero menjadi informasi berharga sebagai dasar dalam penanganan kekurangan gizi pada anak, yaitu dengan memanfaatkan seoptimal mungkin potensi alam dan potensi masyarakat. Kegiatan masak abereng sejalan dengan program pemerintah, yaitu program Pemberian Makanan Tambahan (PMT) sebagai upaya pemulihan gizi pada balita kurang gizi.

\section{Kesimpulan}

Kegiatan masak abereng menjadi salah satu potensi masyarakat dan keluarga di desa dalam peningkatan status gizi balita stunting dengan pendekatan agronursing. Kegiatan masak abereng memberikan gambaran pemenuhan gizi pada balita yang dilakukan oleh keluarga. Keluarga memberikan makanan olahan dari bahan pangan alami yang didapat dari lingkungan setempat. Program masak abereng ini dapat dijadikan bentuk intervensi dalam mengatasi masalah stunting dengan mengintegrasikannya bersama kegiatan posyandu setempat.

\section{Ucapan terima kasih}

Ucapan terima kasih kami sampaikan kepada Lembaga Penelitian dan Pengabdian, Universitas Jember atas pendanaan program Hibah Unggulan Pengabdian Masyarakat tahun 2018, Kelompok Riset Family and Health Care Studies, Departemen Keperawatan Komunitas Keluarga dan Gerontik, Fakultas Keperawatan, Universitas Jember atas tindak lanjut hasil penelitian untuk diwujudkan dalam pengabdian masyarakat ini, dan masyarakat desa di Panti, Kabupaten Jember atas kesediannya berpartisipasi dalam kegiatan pengabdian masyarakat ini.

\section{Daftar pustaka}

1. Kementerian Kesehatan Republik Indonesia. Buku panduan GERMAS. Jakarta: Kementerian Kesehatan Republik Indonesia; 2015.
2. Kementerian Kesehatan Republik Indonesia. Pedoman umum Program Indonesia Sehat dengan pendekatan keluarga. Kementerian Kesehatan Republik Indonesia; 2016.

3. Syahrul S, Kimura R, Tsuda A, Susanto T, Saito $R$, Ahmad F. Prevalence of underweight and overweight among school-aged children and it's association with children's sociodemographic and lifestyle in Indonesia. Int J Nurs Sci. 2016;3:169-77.

4. Syahrul S, Kimura R, Tsuda A, Susanto T, Saito R, Agrina A. Parental perception of the children's weight status in Indonesia. Nurs Midwifery Stud. 2016;6:1-8.

5. Program Profesi Pendidikan Ners. Laporan praktek profesi keperawatan komunitas dan keluarga. Jember: (Indonesia): Universitas Jember, Program Profesi Pendidikan Ners; 2018.

6. Susanto T, Syahrul, Sulistyorini L, Rondhianto, Yudisianto A. Local-food-based complementary feeding for the nutritional status of children ages 6-36 months in rural areas of Indonesia. Korean J Pediatr. 2017;60(10):320-6.

7. Susanto T, Purwandari R, Wuryaningsih EW. Model kesehatan keselamatan kerja berbasis agricultural nursing: Studi analisis masalah kesehatan petani. J Ners. 2016;11(1):45-50.

8. Fahmida U, Santika O, Kolopaking R, Ferguson E. Complementary feeding recommendations based on locally available foods in Indonesia. Food Nutr Bull. 2014;35 Suppl 4:S174-9.

9. Hlaing LM, Fahmida U, Htet MK, Utomo B, Firmansyah A, Ferguson EL. Local food-based complementary feeding recommendations developed by the linear programming approach to improve the intake of problem nutrients among 12-23-month-old Myanmar children. Br J Nutr. 2015;116 Suppl 1:S16-26.

10. Departemen Kesehatan Republik Indonesia. Pedoman umum pemberian Makanan Pendamping Air Susu Ibu (MP-ASI lokal). Jakarta: Departemen Kesehatan Republik Indonesia; 2006.

11. Anderson ET, McFarlane JM. Community as 
partner : Theory and practice in nursing. Am J Nurs. 1996;96(10).

12. Susanto T, Sulistyorini L. Family Friendly dalam optimalisasi keberlangsungan pemberian ASI Ekslusif melalui Integrasi FCN dan TNM di Jember. Jurnal INJEC. 2014;1(2):156-66.

13. Rondhianto, Susanto T, Sulistyorini L. Gerakan Bebas Gizi Buruk (Gerbasgibur) melalui nursing feeding center dalam posyandu plus di Kecamatan Jelbuk Kabupaten Jember. In: Posiding Seminar Nasional 'Kontribusi Penelitian dan PPM dalam Menghasilkan Insan Humanis dan Profesional'; Yogyakarta. LPPM Universitas Negeri Yogyakarta; 2014. p. 86105.

14. Doub AE, Moding KJ, Stifter CA. Infant and maternal predictors of early life feeding decisions. The timing of solid food introduction. Appetite. 2015;92:261-8.

15. Sandjaja S, Budiman B, Harahap H, Ernawati F, Soekatri M, Widodo $\mathrm{Y}$, et al. Food consumption and nutritional and biochemical status of 0.5-12-year-old Indonesian children: the SEANUTS study. Br J Nutr. 2013;(110) Suppl 3:S11-20.

16. Susanto T. Pengaruh terapi keperawatan keluarga terhadap tingkat kemadirian keluarga dengan permasalahan kesehatan reproduksi pada remaja di kelurahan Ratujaya Kecamatan Pancoran Mas Kota Depok. J. Keperawatan. 2010;1(2):190-8.

17. Huriah $T$, Trisnantoro L, Haryanti $F$, Julia $M$. Upaya peningkatan status gizi balita malnutrisi akut berat melalui program home care. J Kesehat Masy Nas. 2014;9(2);129-35.

18. Susanto T. Public health nurse services for maternal-child immigrant healthcare: A literature review. Cent Eur J Nurs Midwifery. 2018;9(3):848-54.

19. Susanto T. Buku ajar keperawatan keluarga: Aplikasi teori pada praktik asuhan keperawatan keluarga. Palembang: CV. Trans Info Media; 2012. 